\title{
Simulasi Pertumbuhan Scalable Business Process Model pada ERP Pondok Pesantren berbasis Production Rule Cellular Automata
}

\author{
Siti Muslihaeny ${ }^{1, *}$, Muhammad Ainul Yaqin ${ }^{2}$, Syahiduz Zaman ${ }^{3}$ \\ Jurusan Teknik Informatika, Universitas Islam Negeri Maulana Malik Ibrahim, Indonesia \\ ${ }^{1}$ heny.rr@yahoo.com, ${ }^{2}$ yaqinov@gmail.com \\ * corresponding author
}

ARTIKEL INFO

Article history

Diterima: 15 Oktober 2019

Direvisi: 5 November 2019

Diterbitkan: 30 Desember 2019

Keywords

Proses Bisnis Pondok Pesantren

Model Petri Net

Control Flow Complexity

Scalability,

Simulasi Pertumbuhan Proses Bisni

Production Rule Cellular Automata.

\section{ABSTRAK}

Penelitian ini bertujuan untuk mensimulasi scalable business process model dari ERP Pondok Pesantren guna mendapatkan variasi proses bisnis yang mungkin terjadi menggunakan teori Production Rule Cellular Automata. Inputan untuk sistem ini adalah model proses bisnis dari empat tipe Pondok Pesantren yang dimodelkan menggunakan Petri net berupa file PNML. Parameter yang digunakan untuk mensimulasikan pertumbuhan proses bisnis adalah scalability. Scalability / skalabilitas adalah potensi proses bisnis untuk tumbuh atau kemampuan pertumbuhan dari proses bisnis. Nilai scalability dapat diukur dengan perhitungan kemiripan workflow dan skala model proses bisnis. Pertumbuhan proses bisnis terjadi pada model A dengan pembanding model B. Syarat untuk dapat terjadi pertumbuhan pada proses bisnis yaitu complexity model A harus lebih kecil daripada model B. Pola pertumbuhan proses bisnis dilakukan secara random dengan dua pembobotan yaitu secara percabangan dan sequence. Pertumbuhan berhenti jika scalabiltiy pada nilai " $>=0$ " dan " $<1$ " Hasil dari penelitian ini menunjukkan bahwa sistem mampu melakukan simulasi pertumbuhan pada file PNML yang ditandai dengan nilai recent scalability lebih kecil dibandingkan scalability awal. Kemudian output sistem adalah file PNML hasil dari simulasi pertumbuhan proses bisnis dengan pertumbuhan elemen baru. Berdasarkan hasil pengujian dari segi nilai scalability, penelitian terbukti berhasil dengan fakta penurunan nilai scalability.

\section{PENDAHULUAN}

Proses bisnis merupakan salah satu elemen penting dari sebuah enterprise. Semakin baik proses bisnis maka semakin baik pula enterprise tersebut [1]. Peningkatan kapasitas produksi dalam enterprise dapat menjadi penyebab peningkatan proses produksi dan proses bisnis. Peningkatan kapasistas produksi dan proses bisnis dapat diprediksi menggunakan simulasi pertumbuhan proses bisnis. Namun, simulasi pertumbuhan proses bisnis harus disesuaikan kembali dengan kebutuhan enterprise. Contoh kebutuhan enterprise yang menjadi pemicu tumbuhnya proses bisnis pada studi kasus Pondok Pesantren yaitu pertambahan jumlah santri dan kurikulum, sehingga memicu adanya penambahan kelas, penambahan jam mata pelajaran dan lain sebagainya. Pada penelitian ini, terdapat beberapa rumusan masalah yaitu bagaimana membuat pola dan mensimulasikan pertumbuhan scalable business process model pada ERP Pondok Pesantren menggunakan Production Rule Cellular Automata serta menghitung keakuratan pola pertumbuhan tersebut. Simulasi pertumbuhan proses bisnis dapat dilakukan apabila proses bisnis tersebut scalable, artinya proses bisnis yang memiliki kemampuan untuk tumbuh. Rumus yang digunakan untuk mengukur proses bisnis scalable dengan perhitungan scalability. Nilai scalability sendiri dapat diukur dengan perhitungan kemiripan workflow dan skala model proses bisnis. Nilai 
skala didapatkan dari hasil perhitungan beberapa parameter yaitu jumlah elemen model proses bisnis dan Control Flow Complexity (CFC) [2]. Selanjutnya, model proses yang scalable akan disimulasikan pertumbuhannya menggunakan Production Rule Cellular Automata. Nantinya simulasi pertumbuhan yang dilakukan pada model proses bisnis dimodelkan dengan Petri net, karena pemodelan menggunakan Petri net lebih sederhana dibandingkan dengan pemodelan lain. Tujuan dari simulasi pertumbuhan proses bisnis pada penelitian ini adalah mengetahui variasi proses bisnis mungkin terjadi dari berbagai kemungkinan.

\section{Enterprise Resource Planning Pondok Pesantren}

\section{KAJIAN TEORI}

Menurut Wijaya dan Darudito, Enterprises Resource Planning (ERP) merupakan singkatan dari tiga elemen kata yaitu Enterprise (Perusahaan), Resource (Sumber Daya) dan Planning (Perencanaan) [3]. Arti luas pengertian ERP sendiri merupakan konsep untuk merencanakan dan mengelola sumber daya perusahaan. Keuntungan dari ERP yaitu paket program terintegrasi dan multifungsi yang dirancang untuk melayani berbagai fungsi di dalam perusahaan sehingga pekerjaan lebih efisien dan menghasilkan nilai tambah bagi semua pihak (stakeholder). Pondok pesantren merupakan salah satu lembaga pendidikan Islam subkultural Indonesia. Pondok pesantren dapat dianalogikan sebagai enterprise, oleh karena itu proses bisnis yang terdapat pada pondok pesantren membutuhkan adanya perencanaan yang baik dan tepat sehingga untuk mengelolanya diperlukan ERP. ERP Pondok Pesantren membutuhkan pemodelan yang berguna untuk mendeskripsikan bagaimana alur sistem pada pondok tersebut [4].

\section{Pemodelan Proses Bisnis}

Pemodelan proses bisnis atau business process model (BPM) merupakan diagram umum yang mewakili urutan kegiatan. Menurut Puspa Dewi, pemodelan proses bisnis merupakan cara untuk mendesain, menganalisa dan memahami proses bisnis. Hal ini memberikan manfaat untuk enterperise memahami proses bisnis, mengidentifikasi masalah yang mungkin terjadi, mendokumentasi sehingga dapat mengkomunikasikan ke stakeholder [5]. Salah satu pemodelan proses bisnis yang digunakan untuk memodelkan proses bisnis adalah Petri net. Petri net adalah bahasa grafis dan matematis untuk pemodelan dan menganalisis proses bisnis. Menurut Anggrainingsih (2004), Petri net dibuat oleh ilmuan bernama Carl Adam Petri tahun 1962 sebagai alat pemodelan yaitu: place, transition dan arc [6]. Arc sebagai penghubung antara place dan transition. Place digambarkan dengan bentuk bulat yang merepresentasikan kondisi yang harus dipenuhi. Transition digambarkan dengan kotak presegi menggambarkan suatu peristiwa (event) atau tindakan. Sebuah transition memiliki input dan output places yang merepresentasikan pre-condition dan post-condition dari event. Place, transition dan arc dinotasikan dalam Gambar 1.

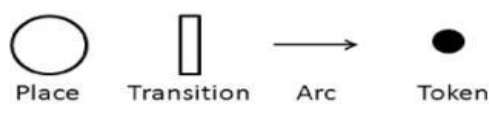

Gambar 1 Notasi Petri net

\section{Skalabilitas Proses Bisnis}

Skalabilitas proses bisnis atau scalability adalah efisiensi menangani pertumbuhan proses bisnis yang semakin kompleks dengan pertimbangan dapat meminimalisir biaya yang akan dikeluarkan serta meningkatkan kinerja dari hasil analisis proses bisnis. Scalability dapat diukur dengan meibatkan beberapa parameter yaitu: structural similarity, behavioral similarity, skala model, kompleksitas dan jumlah elemen dalam proses bisnis [2]. 


\section{Simulasi Pertumbuhan Proses Bisnis}

Simulasi pertumbuhan proses bisnis membantu enterperise dengan melakukan analisa dan pemahaman lebih lanjut mengenai proses bisnis. Tujuan dari simulasi pertumbuhan proses bisnis adalah optimasi untuk meningkatkan kinerja dan pengurangan biaya selaras dengan semakin kompleksnya proses bisnis. Simulasi terkait dengan scalability yaitu menghitung skala dari proses bisnis yang akan disimulasi. Pertumbuhan proses bisnis digunakan untuk menumbuhkan proses bisnis agar menghasilkan variasi proses bisnis dengan berbagai kemungkinan. Simulasi pertumbuhan membutuhkan beberapa aturan dan kriteria untuk menumbuhkan proses bisnis. Salah satu teori yang sering digunakan oleh beberapa peneliti yaitu L-System untuk simulasi pertumbuhan tanaman [7]. Simulasi pertumbuhan dimungkinkan dapat direpresentasikan ke dalam simulasi pertumbuhan suatu graph. Namun, sebelum adanya teori L-System terdapat teori Automata yang dalam cakupannya terdapat Production Rule Cellular Automata yang nantinya akan digunakan pada penelitian ini. Production Rule Cellular Automata merupakan bagian di dalam Cellular Automata. Cellular Automata adalah model diskrit pada ilmu komputer, matematika, fisika, ilmu kompleksitas, biologi teoritis dan pemodelan Cellular Automata juga disebut runag cellular, tessellation automata, struktur homogen, struktur cellular, struktur tesselation dan array yang berulang-ulang [8].

\section{Desain Penelitian}

\section{METODE}

Aplikasi yang akan dibangun adalah aplikasi untuk mensimulasikan pertumbuhan scalable business process model yang artinya proses bisnis yang ditumbuhkan harus scalable. Proses bisnis yang scalable artinya proses bisnis yang terukur serta dapat dihitung dengan menggunakan rumus scalability.

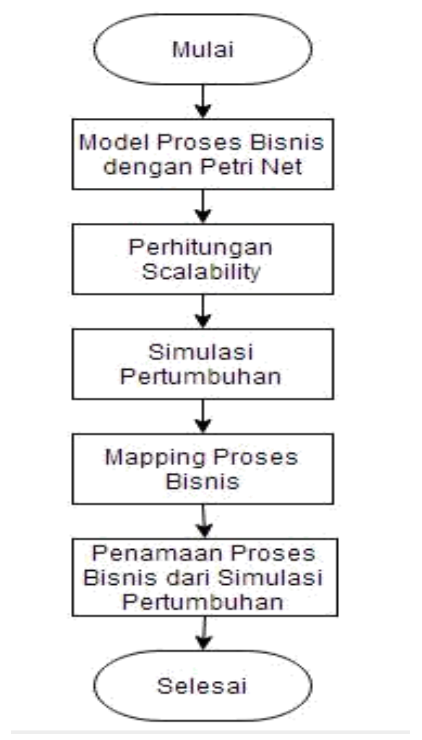

Gambar 2. Prosedur Penelitian

Kemudian, proses bisnis yang scalable disimulasikan pertumbuhannya yang dapat menghasilkan beberapa variasi proses bisnis dari berbagai kemungkinan. Teori yang digunakan dalam penelitian ini adalah Production Rule Cellular Automata. Adapun prosedur penelitian ini menjelaskan bagaimana pelaksanaan penelitian. Prosedur penelitian digambarkan secara umum seperti pada Gambar 2. 


\section{Model Proses Bisnis dengan Petri net}

Data yang digunakan dalam penelitian ini berupa data proses bisnis yakni seperti workflow.pnml yang digambarkan dengan Petri net. Berikut salah satu data pemodelan proses bisnis dengan Petri net ditunjukkan seperti pada Gambar 3.

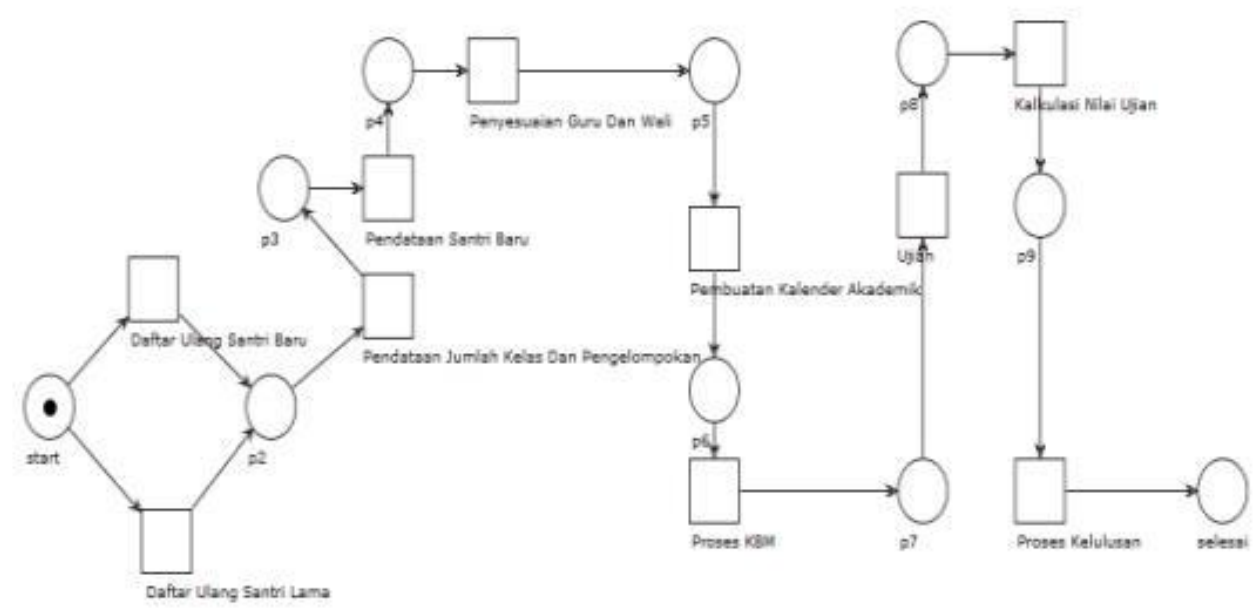

Gambar 3. Proses bisnis Akademik Modern

\section{Perhitungan Scalability}

Nilai scalability dapat diukur dengan melibatkan beberapa parameter yaitu: structural similarity, behavioral similarity, skala model, kompleksitas dan jumlah elemen model proses bisnis.

\section{Simulasi Pertumbuhan Proses Bisnis}

Terdapat beberapa syarat yang harus ada dalam mensimulasikan pertumbuhan proses bisnis yaitu proses bisnis yang scalable. Algoritma yang diusulkan untuk simulasikan pertumbuhan proses bisnis. Parameter yang digunakan untuk mensimulasikan adalah proses bisnis awal dan scalability matriks. Algoritma diatas mengadopsi dari Production Rule Cellular Automata [3].

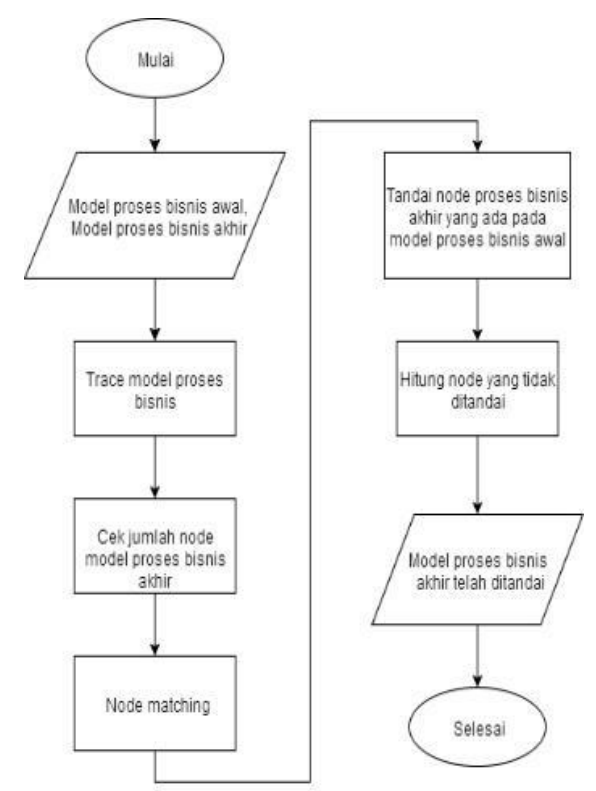

Gambar 4. Algoritma Mapping model proses bisnis 


\section{Mapping Model Proses Bisnis}

Mapping model proses bisnis berguna untuk mengetahui elemen baru setelah simulasi pertumbuhan proses bisnis. Hal ini dapat digunakan sebagai perbandingan proses bisnis awal dengan proses bisnis yang baru. Pemetaan proses bisnis masih dilakukan secara manual, maka diusulkan algoritma seperti Gambar 4.

\section{Penamaan Model Proses Bisnis dari Simulasi Pertumbuhan}

Penamaan pada model proses bisnis yang dimaksudkan adalah penamaan elemen baru pada model proses bisnis dari hasil simulasi pertumbuhan.

\section{PEMBAHASAN}

\section{Perhitungan Structural dan Behavioral Similarity}

Model PNML yang digunakan sebagai data uji merupakan proses bisnis dari empat tipe Pondok Pesantren yaitu: Mahasiswa, Modern, Salaf dan Tahfidz. Data tersebut akan dijadikan masukan untuk dilakukan proses perhitungan structural dan behavioral similarity. Perhitungan perhitungan structural maupun behavioral menggunakan empat algoritma yaitu: Jaccard Coefficient Similarity, Overlap Coefficient Similarity, Dice Coefficient Similarity dan Cosine Coefficient Similarity.

\section{Skalabilitas Proses Bisnis}

Skalabilitas proses bisnis adalah perhitungan dengan mencari nilai scalability daari dua model proses bisnis yang dibandingkan. Nilai scalability diukur dengan beberapa parameter diantaranya: structural similarity, behavioral similarity, skala model, complexity dan jumlah elemen. Sebelum dilakukan perhitungan scalability, dilakukan perhitungan Control Flow Complexity (CFC) pada masing-masing model PNML. Perhitungan CFC adalah menghitung jumlah logika AND-split dan XOR-split yang ada di dalam model PNML. Perhitungan Control Flow Complexity yang mana akan ditunjukkan pada kode program berikut ini:

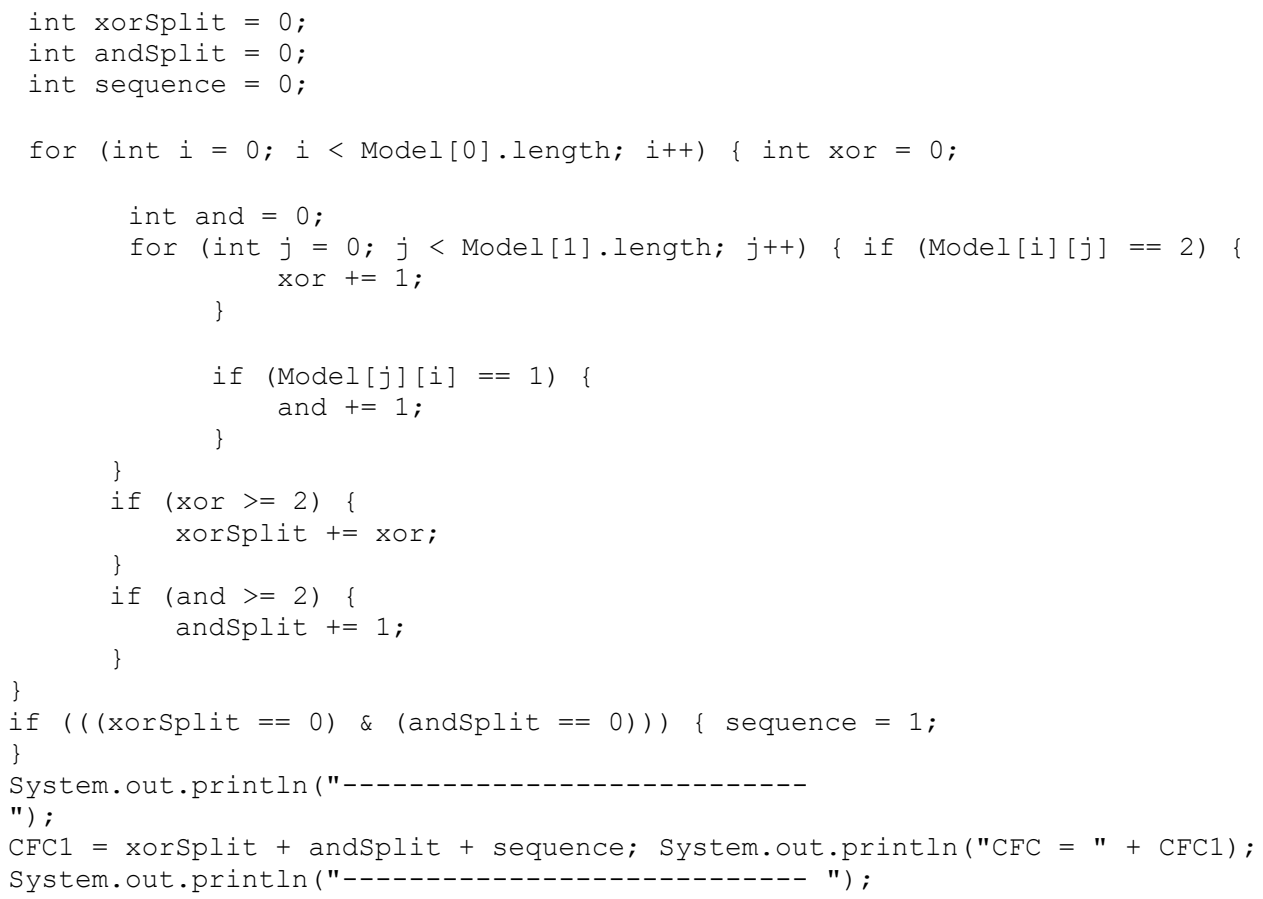


Perhitungan scalability ditangani oleh method skalability(int A, int B, int CFC11, int CFC22). Berikut kode sumber yang digunakan untuk menghitung nilai scalability pada dua model PNML yang ditunjukkan pada kode program di bawah ini:

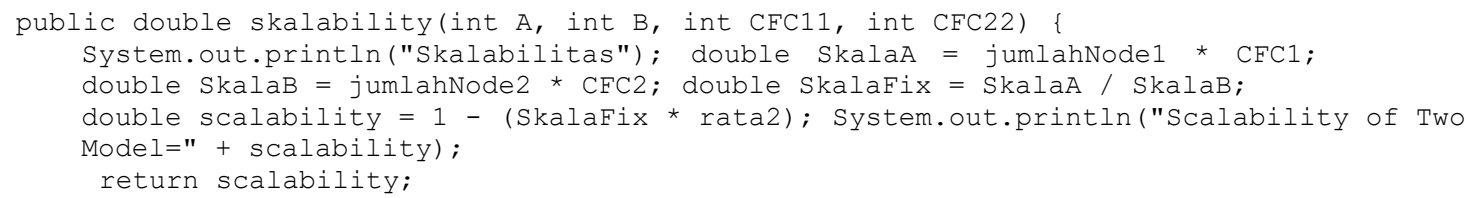

\section{Simulasi Pertumbuhan Proses Bisnis}

Simulasi pertumbuhan proses bisnis pada aplikasi ini menggunakan Production Rule Cellular Automata. Langkah untuk simulasi pertumbuhan proses bisnis pada penelitian ini sebagai berikut: Pertama, meng-input-kan dua data uji dari tipe pondok yang berbeda dengan bagian yang sama. Misal: Proses Bisnis Akademik Modern sebagai input-an A dibandingkan dengan Proses Bisnis Akademik Mahasiswa sebagai input-an B. Kedua, menghitung structural dan behavioral similarity dari kedua model PNML tersebut. Ketiga, menghitung nilai scalability dari kedua input-an model PNML. Jika nilai scalability yang ditemukan pada perhitungan pertama adalah " $>=0$ " dan " $<1$ " maka dilakukan simulasi pertumbuhan. Tetapi penulis membuat syarat tambahan yaitu jika scalability pada iterasi ke-0 atau scalability awal bernilai " $<0.1$ ", maka simulasi pertumbuhan tidak terjadi. Terdapat kriteria dalam menentukan input-an A dan input-an B. Input-an A harus mempunyai nilai complexity yang lebih rendah dibandingkan dengan input-an $\mathrm{B}$. Pertumbuhan proses bisnis yang dimaksud adalah dengan menumbuhkan tiga elemen / node pada model PNML input-an A. Tiga node tersebut yaitu: arc, place dan transisi. Pola pertumbuhan proses bisnis dapat dilakukan dengan dua pembobotan pada proses simulasi pertumbuhan proses bisnis pada penelitian ini yaitu:

1. Pembobotan percabangan

Pembobotan percabangan yang dimaksudkan adalah simulasi pertumbuhan elemen pada model Petri net cenderung ke arah percabangan

2. Pembobotan Sequence

Pembobotan sequence yang dimaksudkan adalah simulasi pertumbuhan elemen pada model PNML cenderung ke arah sequence / tanpa adanya percabangan dalam penumbuhan elemen baru.

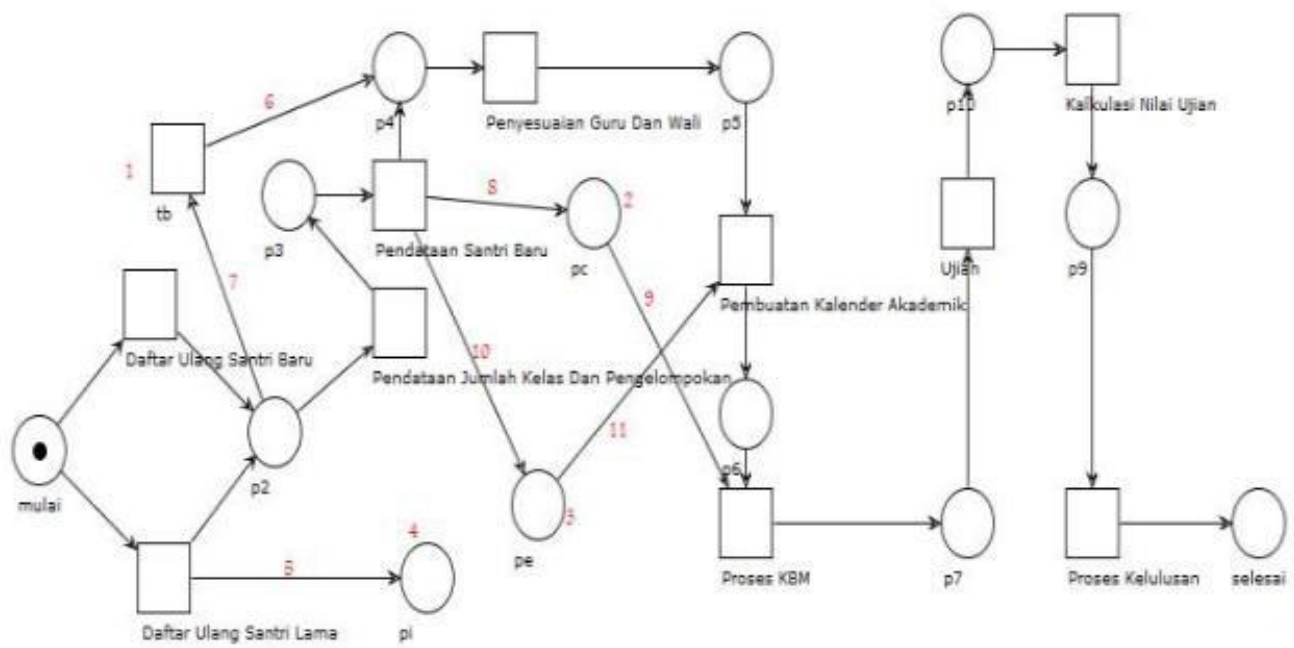

Gambar 5. Output dari Simulasi Pertumbuhan Proses Bisnis 
Hasil dari pertumbuhan model proses bisnis dengan adanya elemen baru yaitu place, transisi dan arc yang ditunjukkan pada Gambar 6. Berdasarkan Gambar 6 di atas, file Petri net hasil dari pertumbuhan proses bisnis yang mana terdapat elemen baru setelah dilakukannya simulasi pertumbuhan proses bisnis. Elemen baru pada pemodelan Petri net ditandai dengan penomoran bewarna merah.

\section{Pengujian Sistem pada Pertumbuhan Proses Bisnis}

Nilai scalability pada bagian Akademik. Berikut ditemukan nilai scalability dari perbandingan model PNML dari bagian Akademik yang ditunjukkan pada Tabel di bawah ini:

Tabel 1. Perbandingan Nilai Scalability Akademik

\begin{tabular}{|c|c|r|r|r|}
\hline $\begin{array}{c}\text { Model B } \\
\text { Model A }\end{array}$ & $\begin{array}{c}\text { Akademik } \\
\text { Tahfidz }\end{array}$ & $\begin{array}{c}\text { Akademik } \\
\text { Modern }\end{array}$ & $\begin{array}{c}\text { Akademik } \\
\text { Salaf }\end{array}$ & $\begin{array}{r}\text { Akademik } \\
\text { Mahasiswa }\end{array}$ \\
\hline $\begin{array}{c}\text { Akademik } \\
\text { Tahfidz }\end{array}$ & 0.0 & 0.48605105 & 0.58109385 & 0.60040077 \\
\hline Akademik & - & 5 & 8 & 6 \\
Modern & & 0.0 & 0.56588114 & 0.56370029 \\
\hline $\begin{array}{c}\text { Akademik } \\
\text { Salaf }\end{array}$ & - & - & 0.0 & 0.20896176 \\
\hline Akademik & - & - & & 5 \\
\hline
\end{tabular}

Dari Tabel 1 di atas, didapatkan variasi nilai scalability dengan membandingkan dua model PNML dari bagian Akademik. Jika complexity input-an A > input-an B, maka tidak dapat dilakukan simulasi pertumbuhan. Begitu juga sebaliknya, jika complexity input-an A < input-an B, maka dapat dilakukan simulasi pertumbuhan. Namun, jika pada tabel di atas terdapat kolom yang isinya tanda "." artinya perbandingan antar dua model PNML menghasilkan nilai scalability tetapi tidak dapat dilakukan simulasi pertumbuhan. Jika membandingkan input-an A dan input-an B dengan model PNML yang sama, maka nilai scalability akan otomatis bernilai nol. Berikut ditunjukkan hasil simulasi pertumbuhan dari Akademik Modern sebagai input-an A dan Akademik Mahasiswa sebagai input-an B pada Tabel 2.

Menurut Tabel 2, simulasi pertumbuhan percobaan pertama dan kedua pada pembobotan percabangan mendapatkan hasil iterasi yang berbeda. Sedangkan pada pembobotan sequence, percobaan pertama dan kedua mendapatkan hasil iterasi dan nilai minimum scalability yang sama. Dilakukan juga simulasi pertumbuhan dengan pola AND, artinya percabangan yang lebih ke arah logika AND dan mendapatkan hasil iterasi yang berbeda. Seperti yang telah dipaparkan, nilai scalability awal pada perbandingan proses bisnis Akademik Modern dan proses bisnis Akademik Mahasiswa adalah 0.486051055, maka simulasi pertumbuhan dapat terjadi. Simulasi pertumbuhan dilakukan dengan pembobotan pada percabangan dan sequence. Hasil simulasi pertumbuhan pada pembobotan percabangan dan sequence akan mendapatkan iterasi berbeda. Hal ini dikarenakan simulasi pertumbuhan elemen pada proses bisnis dilakukan secara random. Oleh karena itu, hasil simulasi pada percobaan pertama, kedua dan seterusnya akan berbeda. Namun, tidak menutup kemungkinan mendapatkan nilai iterasi yang sama. Nilai scalability terus mengalami penurunan seiring dengan bertambahnya iterasi pertumbuhan pada proses bisnis. Iterasi pertumbuhan menyebabkan scalability bernilai " $>=0$ ", artinya nilai scalability tidak sampai bernilai minus. Namun, pada iterasi terakhir, scalability dapat bernilai minus karena pada iterasi sebelumnya scalability terindentifikasi bernilai " $>=0$ " dan akan berlanjut pertumbuhannya. Hal ini menyebabkan scalability pada iterasi terakhir bernilai minus. Sehingga, nilai scalability minimum terletak pada iterasi sebelum iterasi terakhir. 
Tabel 2. Simulasi Pertumbuhan Akademik Modern \& Akademik Mahasiswa

\begin{tabular}{|c|c|c|c|c|c|}
\hline \multicolumn{6}{|c|}{ PERCABANGAN } \\
\hline \multirow{13}{*}{ 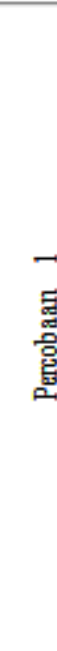 } & $\begin{array}{l}\text { Model B } \\
\text { ModelA }\end{array}$ & $\begin{array}{c}\text { Akademik } \\
\text { Mahasiswa }\end{array}$ & \multirow{13}{*}{$\begin{array}{l}\text { 总 } \\
\text { 芯 } \\
\text { 总 }\end{array}$} & Model B & Akademik \\
\hline & Akademik & 0.56370029 & & Akademik & 0.56370029 \\
\hline & Modern & & & Modern & \\
\hline & Iterasi 1 & 0.32942754 & & Iterasi 1 & 0.55295169 \\
\hline & & & & & \\
\hline & Iterasi 2 & 0.30146158 & & Iterasi 2 & 0.30146158 \\
\hline & & 0.31010000 & & & 031910089 \\
\hline & lterasi 3 & $\begin{array}{r}0.31910089 \\
2\end{array}$ & & Iterasi 3 & $\begin{array}{r}0.31910089 \\
2\end{array}$ \\
\hline & Iterasi 4 & 0.11803261 & & Iterasi 4 & 0.11803261 \\
\hline & Iterasi 5 & & & Iterasi 5 & 0.09685211 \\
\hline & & 0.35472182 & & & 6 \\
\hline & Iterasi 6 & & & Iterasi 6 & \\
\hline & & & & & $\begin{array}{r}0.52862590 \\
8\end{array}$ \\
\hline & & & & & \\
\hline \multirow{7}{*}{$\begin{array}{l}\mathrm{A} \\
\mathrm{N} \\
\mathrm{D}\end{array}$} & Iterasi 1 & 0.55295169 & \multirow{7}{*}{$\begin{array}{l}\mathrm{X} \\
\mathrm{O} \\
\mathrm{R}\end{array}$} & & - \\
\hline & Iterasi 2 & 0.30146158 & & & - \\
\hline & Iterasi 3 & 0.26337732 & & & - \\
\hline & & & & & \\
\hline & Iterasi 4 & 0.11605279 & & & - \\
\hline & \multirow[t]{2}{*}{ lterass } & & & & - \\
\hline & & $\begin{array}{r}0.03127174 \\
3\end{array}$ & & & \\
\hline \multirow{12}{*}{ 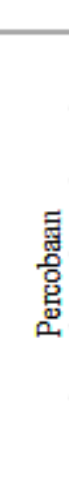 } & \multicolumn{5}{|c|}{ SEQUENCE } \\
\hline & Model B & \multirow{11}{*}{\begin{tabular}{|c|c}
$\begin{array}{c}\text { Akademik } \\
\text { Mahasiswa }\end{array}$ \\
0.56370029 \\
3 \\
0.32000697 \\
0 \\
0.15624724 \\
7 \\
0.09213452 \\
\end{tabular}} & \multirow{11}{*}{ 营 } & Model B & Akademik \\
\hline & Model A & & & Model A & Mahasiswa \\
\hline & Akademik & & & Akademik & 0.56370029 \\
\hline & Modern & & & Modern & \\
\hline & Iterasi 1 & & & Iterasi 1 & 0.32000697 \\
\hline & & & & & 0 \\
\hline & Iterasi 2 & & & Iterasi 2 & 0.17671627 \\
\hline & & & & & \\
\hline & Iterasi 3 & & & Iterasi 3 & 0.15624724 \\
\hline & Iterasi 4 & & & Iterasi 4 & 0.09213452 \\
\hline & & & & & \\
\hline
\end{tabular}

\section{KESIMPULAN}

Berdasarkan penelitian yang telah dilaksanakan, dapat disimpulkan bahwa Proses perhitungan structural dan behavioral similarity menggunakan empat algoritma yaitu: Jaccard Coefficient Similarity, Overlap Coefficient Similarity, Dice Coefficient Similarity dan Cosine Coefficient Similarity. Terbukti bahwa keempat algoritma tersebut dapat melakukan perhitungan mencari kemiripan model PNML pada proses bisnis Pondok Pesantren Salaf Anwarul Huda Malang (tipe pondok salaf), Pondok Pesantren Modern ArRifaie 1 Gondanglegi (tipe pondok modern), Pondok Pesantren Mahasiswa Syai Urrifa' Malang (tipe pondok mahasiswa) dan Pondok Pesantren Ar-Rohmah Malang (tipe pondok tahfidz). Selanjutnya, dilakukan perhitungan scalability dengan menggunakan beberapa parameter yaitu: similarity workflow, jumlah elemen proses bisnis, complexity dan skala proses bisnis. Nilai scalability digunakan untuk untuk menentukan pola pertumbuhan 
proses bisnis. Pola pertumbuhan proses bisnis dilakukan dengan dua pendekatan yaitu: secara sequence dan percabangan. Simulasi pertumbuhan proses bisnis dengan menerapkan teori Production Rule Cellular Automata untuk menumbuhkan beberapa elemen pada model A dengan pembanding model B. Dilakukan pembobotan atau mengukur ketepatan pola pada saat proses simulasi pertumbuhan pada dua pendekatan percabangan dan sequence. Hasil dari kedua pembobotan akan berpengaruh pada iterasi yang dihasilkan. Meskipun dilakukan berulang kali percobaan simulasi pertumbuhan dengan masing-masing pembobotan, hasil simulasi akan terus berbeda. Hal ini dikarenakan pertumbuhan elemen pada proses bisnis dilakukan secara random. Simulasi pertumbuhan proses bisnis dari segi scalability terbukti berhasil karena adanya penurunan nilai scalability dan perhitungan standart deviasi menghasilkan rata-rata dengan nilai “ $<0.2$ ". Simulasi pertumbuhan proses bisnis dari segi similarity, hasil yang didapatkan belum maksimal karena adanya pertumbuhan random, sehingga rata-rata nilai similarity setelah simulasi " $<0.5$ ". Terbukti berhasil apabila nilai similarity setelah simulasi $>$ sebelum simulasi pertumbuhan.

\section{REFERENSI}

[1] M. M. Essam and S. L. Mansar, "Toward a Software Framework for Automatic Business Process Redesign," in Ain Shams University, Egypt, 2011.

[2] M. Ainul, C. Fauzan, R. Sarno and Wahyu, "Scalability Measurement of Business Process Model Using Business Processes Similarity and Complexity," 2016.

[3] S. F. Wijaya and S. Darudito, ERP (Enterprise Resource Planning) \& Solusi Bisnis, Yogyakarta: Graha Ilmu, 2009.

[4] M. P. Fajarivan, "Integrasi Sistem Keuangan pada Enterprise Resource Planning Pondok Pesantren Tipe Pondok D Menggunakan Services Oriented Architecture,” Malang, 2017.

[5] L. Puspa Dewi, U. Indahyati and Y. Hari S, "Pemodelan Proses Bisnis Menggunakan Activity Diagram UML dan BPMN," 2010.

[6] A. d. Rini, "Analsisis Dan Verifikasi Workflow Menggunakan Petri (Studi kasus: Proses Bisnis di Universitas Sebelas Maret)," in Senimar Nasional Teknologi Informasi \& Komunikasi Terapan 2014, 2014.

[7] Suhartono, Intergration of Artifial Neural Network Into Genetic L-System Programming Based Plant Modeling Environment with Mathematica, Jakarta Pusat: Kementrian Agama Republik Indonesia, 2012.

[8] S. Wolfram, "Statistical Mechanics of Cellular Automata," Vols. Vol. 55, No. 23, no. The Institute for Advanced Study, 1983. 